KAROLINA KRAJČEK NIKOLIĆ, Ph.D. ${ }^{1}$

(Corresponding author)

E-mail: karolina.krajcek@fpz.hr

ANITA DOMITROVIĆ, Ph.D. ${ }^{1}$

E-mail: anita.domitrovic@fpz.hr

SLOBODAN JANKOVIĆ, Ph.D. ${ }^{2}$

E-mail: jeanslobodan@gmail.com

${ }^{1}$ University of Zagreb

Faculty of Transport and Traffic Sciences

Vukelićeva 4, 10000 Zagreb, Croatia

2 University of Zagreb

Faculty of Mechanical Engineering and Naval Architecture

Ivana Lučića 5, 10000 Zagreb, Croatia
Transport Engineering

Preliminary Communication

Submitted: 15 Aug. 2017

Accepted: 5 July 2018

\title{
ESTIMATION OF AERODYNAMIC COEFFICIENTS IN A SMALL SUBSONIC WIND TUNNEL
}

\begin{abstract}
To apply the experimental data measured in a wind tunnel for a scaled aircraft to a free-flying model, conditions of dynamical similarity must be met or scaling procedures introduced. The scaling methods should correct the wind tunnel data regarding model support, wall interference, and lower Reynolds number. To include the necessary corrections, the current scaling techniques use computational fluid dynamics (CFD) in combination with measurements in cryogenic wind tunnels. There are a few methods that enable preliminary calculations of typical corrections considering specific measurement conditions and volume limitation of test section. The purpose of this paper is to present one possible approach to estimating corrections due to sting interference and difference in Reynolds number between the real airplane in cruise regime and its 1:100 model in the small wind tunnel AT-1. The analysis gives results for correction of axial and normal force coefficients. The results of this analysis indicate that the Reynolds number effects and the problem of installation of internal force balance are quite large. Therefore, the wind tunnel AT-1 has limited usage for aerodynamic coefficient determination of transport airplanes, like Dash 8 Q400 analyzed in this paper.
\end{abstract}

\section{KEY WORDS}

wind tunnel corrections; Reynolds number scaling; model support correction;

\section{INTRODUCTION}

Most wind tunnel tests are used with scaled models but with the intention of finding the characteristics of a full-scale aircraft in flight. However, there is a great leap between a small-scale wind tunnel model and a full-scale aircraft in flight. Differences in model fidelity, flow conditions and suspension interferences may cause the scale model test not to be representative of the full-scale aircraft. To evaluate the correction of the measured aerodynamic coefficients, the differences between free flight and tunnel conditions should be identified. There are experimental, empirical, and CFD methods used as correction technique data depending on the flow conditions (Reynolds and Mach number effects), geometry, and types of measurements [1], [2], [3], [4], [5]. Many experimental and empirical methods are used in combination with CFD technology for more accurate results [6], [7], [8].

Among the listed possible sources of differences between free flight testing and wind tunnel testing, this paper is focused on preliminary estimation of measurement errors due to scale effects differences and model-sting interaction for the chosen measurement setup.

The dependency of the aerodynamic properties on the Reynolds number is a typical example of the socalled Reynolds number scaling effects, which play an important role when results from subscale wind-tunnel tests must be extrapolated to flight conditions [9].

The method of measuring aerodynamic coefficients depends on the available working space dimensions. If this space is small, the model size is limited by the available space. The problem is how to organize the measurement given a very small model held on a balance fixed to a sting. The sting should be big enough to accommodate the wires from the balance to the acquisition computer and rigged enough to avoid its bending. The attachment of the sting to the balance must be provided without contact with the model airframe.

The build-up method will be used to evaluate the necessary corrections due to Reynolds number and model support interactions. 


\section{THE PROBLEM AND PROPOSED METHOD}

The Faculty of Transport and Traffic Sciences in Zagreb has a small subsonic wind tunnel named AT-1 and located in the Aerodynamic Laboratory at the University Campus Borongaj. The tunnel has a small open test section with an elliptic cross-section. The test section is $310 \mathrm{~mm}$ high, $352 \mathrm{~mm}$ wide, and $450 \mathrm{~mm}$ long (Figure 1).

The airflow in the tunnel is produced by a single-stage fan powered by a 4-kW variable-speed synchronous motor with a variable-frequency speed controller up to $50 \mathrm{~Hz}$. The maximum air velocity is up to $50 \mathrm{~m} / \mathrm{s}$. The wind tunnel is equipped with a NetScanner Pressure Measuring System on the model. It is mostly used for educational purposes.

To improve the educational and research activities, the wind tunnel facility should be upgraded with an internal strain-gauge balance for measuring the aerodynamic characteristics of aircraft. Since the test section is small, the transport airplane model must be scaled. For example, regional airplane Dash 8 Q400 could be used as a model, but it should be scaled 1:100. In addition, to hold the model inside the test section, the after body must be truncated. The balance-sting connection shown in Figure 2 will be introduced through the rear part of the truncated body. The interfering flow effect due to the presence of the sting, instead of the truncated part of the after body, will be called the sting interference.

The goal of this paper is to make a preliminary estimation of differences between the aerodynamic coefficients of the airplane in flight and its model in the wind tunnel. These differences are due to the sting interference, the fact that the model must be truncated and the difference between the Reynolds number of the airplane in flight and the airplane model in the tunnel. The estimated differences between the aerodynamic coefficients will also be the corrections of the measurements in the wind tunnel to match the free

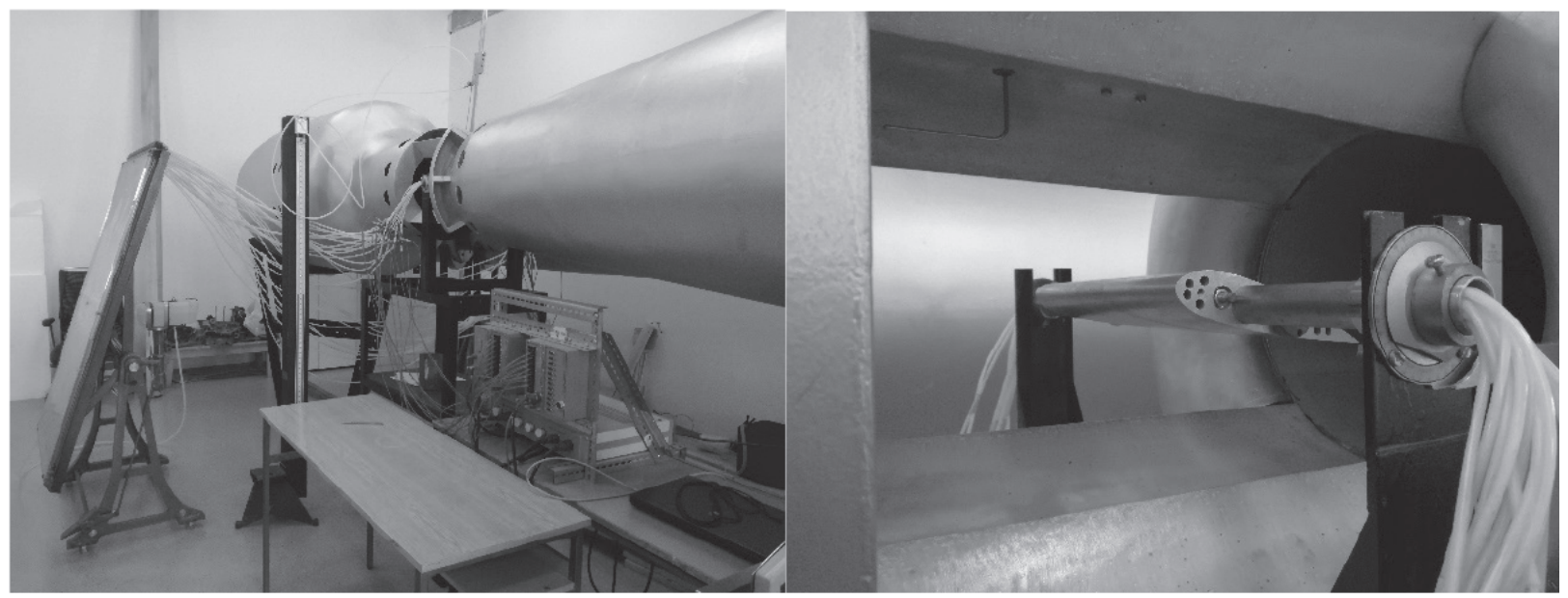

Figure 1 - Test section at small subsonic wind tunnel AT-1

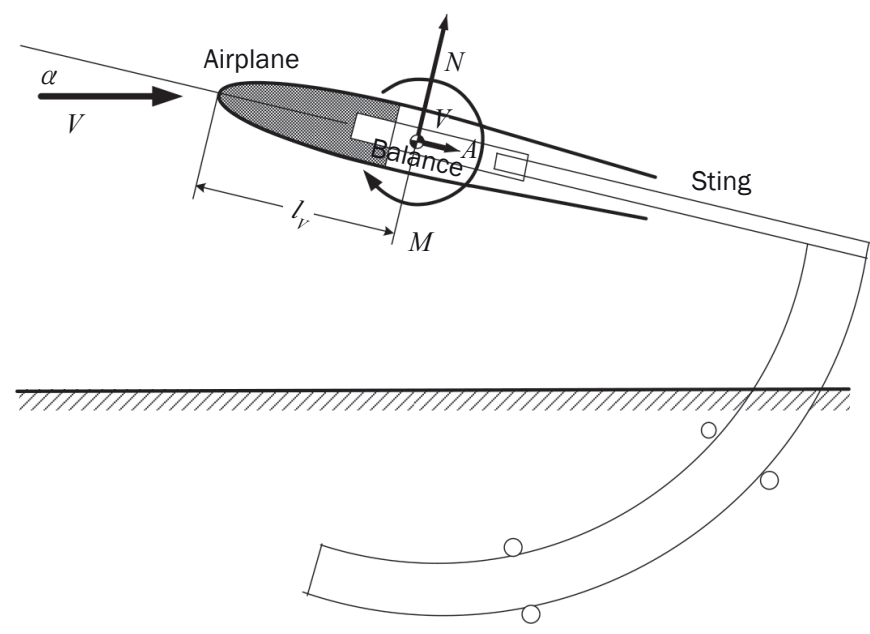

Figure 2 - The aircraft model in the wind tunnel with the sting-balance connection 
flight values. The starting point of the estimation is the basic definition of the aerodynamic force in flight and in the wind tunnel.

\subsection{The aerodynamic coefficients of the airplane in flight and the wind tunnel model}

The aerodynamic coefficients of the airplane in cruise (Figure 3 ) without a sideslip angle are axial force along $x$ axis, $C_{A}$ and normal force along $z$ axis, $C_{N}$ [9]:

$$
\begin{aligned}
C_{A} & =-\frac{1}{S_{r e f}} \int_{S_{e}} C_{p} n_{e x} d S-\frac{1}{S_{r e f}} \int_{S_{e}} \bar{\tau}_{x} d S-C_{p b} \frac{S_{b}}{S_{r e f}} \\
C_{N} & =\frac{1}{S_{r e f}} \int_{S_{e}} C_{p} n_{e z} d S
\end{aligned}
$$

where:

$$
\begin{aligned}
& \vec{n}_{e} \quad \text {-normal on the exterior surface of the } \\
& \text { airplane }\left[n_{e x} n_{e y} n_{e z}\right]^{T} \text {, } \\
& S_{\text {ref }} \quad \text {-the reference aerodynamic surface of } \\
& \text { the airplane, } \\
& S_{b} \quad \text {-cross-sectional area of the base of the } \\
& \text { body, } \\
& S_{e} \quad \text {-exterior surface of the body, wing, } \\
& \text { horizontal and vertical tail, and all others } \\
& \text { parts of the aircraft without the surface } \\
& \text { of the base, } \\
& C_{p} \quad \text { - pressure coefficient, } \\
& \vec{\tau} \quad \text {-the shear stress on the exterior surface } \\
& \begin{array}{c}
\bar{\tau}_{x}=\frac{\tau_{x}}{\rho V^{2}}-\text { dimensionless shear stress on the } \\
2 \quad \begin{array}{l}
\text { exterior surface in the direction of the } x \\
\text { axis, all values for the airplane in flight. }
\end{array}
\end{array}
\end{aligned}
$$

The viscous part of the normal force usually is neglected. Equations 1 and 2 are valid only for aerodynamic coefficients of airplane in flight.

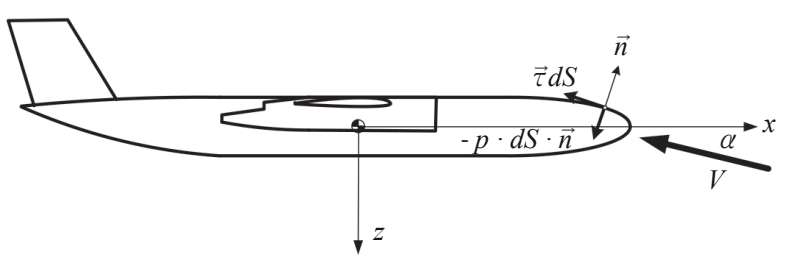

Figure 3 - Aircraft in flight at attack angle $\alpha$ and airspeed $V$
The model of the aircraft for the tunnel measurements is shown in Figure 4. Since the body of the chosen transport aircraft does not have the base to introduce the sting through it, one small part of the after body (normal to the $x$ axes) must be cut off to install the sting. The cross section of the cut part is $S_{0 x}$, as shown in Figure 4. In this setup, the model must not be in contact with the sting during measurements. The diameter of the sting should be small, and at the same time the sting should be rigid enough not to bend more than $0.1^{\circ}$.

Since the model is open at the rear, it is not possible to apply Equations 1 and 2 for estimation of the aerodynamic coefficients. New equations for the aerodynamic coefficients of the model in the tunnel must be developed.

All the values related to the airplane in flight are marked with the index $l$, and all the values of the wind tunnel model with the index $m$.

As there is no flow through the airplane model (no leakage), the inner pressure $p_{r}$ is constant and equal to the pressure measured on the ring $S_{0 x}-S_{S}$ (in the hole around the sting). Let $\vec{F}_{V}$ be the force of the balance acting on the model, therefore the equation of the equilibrium of all forces acting on the model is:

$$
\begin{aligned}
& \vec{F}_{V}+\int_{S_{e}}-p \vec{n}_{e} d S+\int_{S_{e}} \vec{\tau} d S+p_{r} \int_{S_{i}} \vec{n}_{i} d S+p_{r}\left(S_{h}-S_{v}\right) \vec{i}_{x}+ \\
& +p_{r}\left(S_{V}-S_{S}\right) \vec{i}_{x}=0
\end{aligned}
$$

where:

$\vec{n}_{i}$-normal on the inner surface of the model $\left[n_{i x} n_{i y} n_{i z}\right]^{T}$,

$\vec{n}_{e}$-normal on the exterior surface of the model $\left[n_{e x} n_{e y} n_{e z}\right]^{T}$,

$p$ - pressure on the exterior surface,

$p_{r} \quad$-pressure in the ring between the hole of the body and the sting,

$S_{h} \quad$-the inner front surface between the force balance and the body,

$S_{i} \quad$-the inner surface of the model without the front part, which has the same normal as the exterior surface but with opposite sign,

$S_{V}$-transversal surface of the balance,

$S_{s}$-cross section of the sting, are all values of the wind tunnel model.

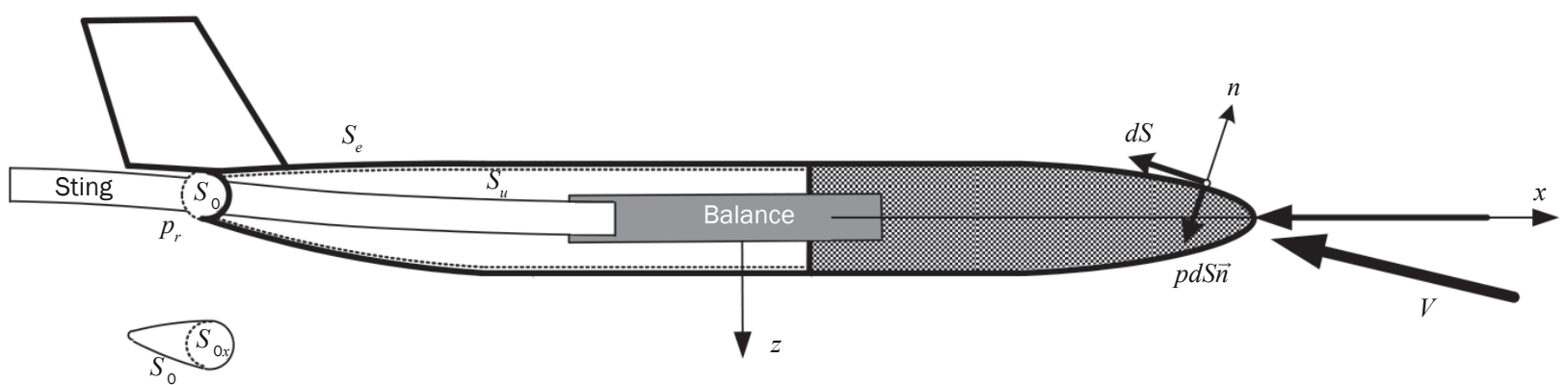

Figure 4 - The aircraft model with cut-off part in the wind tunnel 
As the force $\vec{F}_{V}$ is equal, but in the direction opposite to the aerodynamic force $\vec{F}$ on the model, it follows that

$$
\vec{F}=\int_{S_{e}}-p \vec{n}_{e} d S+\int_{S_{e}} \vec{\tau} d S+p_{r} \int_{S_{i}} \vec{n}_{i} d S+p_{r}\left(S_{h}-S_{S}\right) \vec{i}_{x}
$$

The axial component $A$ of aerodynamic force in Equation 4 along the $x$ axes is equal to:

$$
\begin{aligned}
A & =\int_{S_{e}}-p n_{e x} d S+\int_{S_{e}} \tau_{x} d S+p_{r} \int_{S_{i}} n_{i x} d S+p_{r}\left(S_{h}-S_{S}\right) \\
& =\int_{S_{e}}-p n_{e x} d S+\int_{S_{e}} \tau_{x} d S-p_{r}\left(S_{h}-S_{0 x}\right)+p_{r}\left(S_{h}-S_{s}\right) \\
& =\int_{S_{e}}-p n_{e x} d S+\int_{S_{e}} \tau_{x} d S+p_{r}\left(S_{0 x}-S_{S}\right)
\end{aligned}
$$

When the air is not moving through the wind tunnel, Equation 5 becomes:

$0=\int_{S_{e}}-p_{\infty} n_{e x} d S+p_{\infty}\left(S_{0 x}-S_{s}\right)$

where:

$p_{\infty}$-freestream pressure,

$S_{0}$ - part of the exterior surface $S_{e}$ which is cut-off to allow the sting to enter the body,

$S_{0 x}$ - projection of the surface $S_{0}$ on the transversal plan.

By subtracting Equation 6 from Equation 5 and dividing the result with the model's reference surface $S_{\text {ref }}$ and dynamic pressure in the tunnel's working space, the axial force coefficient of the model $C_{A m}$ is given:

$$
\begin{aligned}
C_{A m}= & -\frac{1}{S_{r e f}} \int_{S_{e}} C_{p} n_{e x} d S+\frac{1}{S_{r e f}} \int_{S_{e}} \bar{\tau}_{x} d S+ \\
& +\frac{1}{S_{r e f}} C_{p r}\left(S_{0 x}-S_{s}\right)
\end{aligned}
$$

where $C_{p r}$ is the pressure coefficient on the ring between the sting and the cut-off surface $S_{0 x}$.

The normal aerodynamic force is obtained by projecting Equation 4 on the $z$ axes. The viscous part is neglected:

$-N=\int_{S_{e}}-p n_{e z} d S$

With the air not moving through the wind tunnel, Equation 8 becomes

$0=\int_{S_{e}}-p_{\infty} n_{e z} d S$

By subtracting Equation 9 from Equation 8 and dividing the result with the reference surface of the model $S_{r e f}$ and dynamic pressure in the tunnel's working space $\rho V^{2} / 2$, the normal force coefficient $C_{N m}$ is given:

$$
C_{N m}=\frac{1}{S_{r e f}} \int_{S_{e}} C_{p} n_{e z} d S
$$

\subsection{The differences between axial coefficients}

The difference between the axial force coefficients for the aircraft in flight and the wind tunnel model is given by equation:

$$
\begin{aligned}
& C_{A l}-C_{A m}=\left(-\frac{1}{S_{r e f}} \int_{S_{e}} C_{p} n_{e x} d S+\frac{1}{S_{r e f}} \int_{S_{e}} \bar{\tau}_{x} d S-C_{p b} \frac{S_{B}}{S_{r e f}}\right)_{l} \\
& -\left(-\frac{1}{S_{r e f}} \int_{S_{e}} C_{p} n_{e x} d S+\frac{1}{S_{r e f}} \int_{S_{e}} \bar{\tau}_{x} d S-C_{p r} \frac{S_{0 x}-S_{s}}{S_{r m}}\right)_{m}
\end{aligned}
$$

It can be observed that Equation 11 has three parts:

1) the difference due to the shear stress or friction,

2) the difference due to the pressure, and

3) the increase of axial coefficient due to model support interferences.

The first part is:

$$
\Delta_{f} C_{A}=C_{A f l}-C_{A f m}=\left(\frac{1}{S_{r e f}} \int_{S_{e}} \bar{\tau}_{x} d S\right)_{l}-\left(\frac{1}{S_{r e f}} \int_{S_{e}} \bar{\tau}_{x} d S\right)_{m}
$$

Even if $\bar{\tau}_{x l}=\bar{\tau}_{x m}$, there would still be the difference due to the different areas of integration because $\left(\frac{S_{e}}{S_{r e f}}\right)_{l} \neq\left(\frac{S_{e}}{S_{r e f}}\right)_{m}$ i.e., $\left(\frac{S_{e}}{S_{r e f}}\right)_{l}=\left(\frac{S_{e}+S_{0}}{S_{r e f}}\right)_{m}$.

The difference component due to shear stress caused by different Reynolds numbers of the flow around the aircraft in flight and around the model in the tunnel is more important than the difference due to the different areas of integration.

The second part of the axial coefficient's difference is:

$$
\Delta_{p} C_{A}=\left(-\frac{1}{S_{r e f}} \int_{S_{e}} C_{p} n_{e x} d S\right)_{l}-\left(-\frac{1}{S_{r e f}} \int_{S_{e}} C_{p} n_{e x} d S\right)_{m}
$$

Therefore, the second part of the difference between axial coefficients has two components:

- First, it has different areas of integration. In the case of the airplane in flight, the exterior surface is complete, since in the case of the model in the tunnel the exterior surface is reduced for the cutoff part $S_{0}$.

- The second component of Equation 13 is due to the different pressure coefficients $C_{p m} \neq C_{p l}$. For subsonic flow, the air perturbation, due to removal of the surface $S_{0}$, is transferred upstream and causes changes of pressure coefficient.

Finally, the third part of Equation 11 is the increase of axial coefficient due to model support interferences:

$\Delta_{s} C_{A}=\left(-C_{p b} \frac{S_{b}}{S_{r e f}}\right)_{l}-\left(-C_{p r} \frac{S_{0 x}-S_{s}}{S_{r e f}}\right)_{m}$

where $C_{p r}$ is the pressure coefficient based on the measured pressure in the ring between the hole and the sting.

\subsection{The differences between normal force coefficients}

Subtracting Equation 2 from Equation 10 yields the difference between normal force coefficients:

$$
\begin{aligned}
\Delta_{p} C_{N} & =C_{N l}-C_{N m}=\left(-\frac{1}{S_{r e f}} \int_{S_{e}} C_{p} n_{e z} d S\right)_{l}- \\
& =-\left(\frac{1}{S_{r e f}} \int_{S_{e}} C_{p} n_{e z} d S\right)_{m}
\end{aligned}
$$


The observation on the different areas of integration is the same as for the axial force coefficient. Therefore, the difference between normal force coefficients also has two components: one due to different areas of integration, and another due to different pressure coefficients $C_{p m} \neq C_{p l}$.

\section{THE EVALUATION OF THE CORRECTIONS}

The corrections introduced in section 2 will be evaluated using a 1:100 model of Dash 8 Q400 regional transport aircraft, part of the Croatian national airlines fleet. The cruise velocity of the airplane is approximately $V=185 \mathrm{~m} / \mathrm{s}$ at the altitude of $H=6,000 \mathrm{~m}$ in standard atmosphere.

\subsection{The first part of the axial correction}

The first part of the correction, i.e., Equation 12, is estimated by the equation

$\Delta_{f} C_{A}=C_{A f l}-C_{A f m} \approx\left(\frac{\sum S_{e i} C_{f i}}{S_{r e f}}\right)_{l}-\left(\frac{\sum S_{e i} C_{f i}}{S_{r e f}}\right)_{m}$

where:

$S_{\text {eli }} \quad$-the exterior surfaces of all parts of the airplane in flight (wetted surfaces of $i$ part) and

$S_{\text {emi }} \quad$-the same for the model in the tunnel.

The friction coefficient for each part $C_{f i}$ is the average skinfriction coefficientforsmooth flatplatethat depends on Reynolds number and is applicable for preliminary calculations. For cruise flight velocity of $185 \mathrm{~m} / \mathrm{s}$ and altitude $6,000 \mathrm{~m}$, and for assumed surface roughness height of $h=10 \mu \mathrm{m}$, the roughness Reynolds number is $R e_{h}=V \cdot h / v=185 \cdot 10 \cdot 10^{-6} / 0.242 \cdot 10^{-4}=76.4$. From [10] it follows that $R e_{t}=1 \cdot 10^{6}$ gives the transition position of $l_{t}=0,170 \mathrm{~m}$. Since the laminar part is very short, it is accepted that the boundary layer of each aircraft part is turbulent. If the surface roughness height was bigger, this assumption would be even more justified, since this means an even shorter laminar boundary layer. For each part of the airplane in flight, the reference length, Reynolds number $R e_{i}$, friction coefficient $C_{f i}$, and wetted surface (Table 1) are calculated.

The total skin friction coefficient for aircraft in flight is:

Table 1 - Friction coefficients for aircraft in flight with $185 \mathrm{~m} / \mathrm{s}$ and at 6,000 m

\begin{tabular}{||c|c|c|c|c|c||}
\hline Part $i$ & Body & Wing & Horizontal tail & Vertical tail & Nacelle \\
\hline \hline$l_{i}[\mathrm{~m}]$ & 32.8 & 2.26 & 1.81 & 3.49 & 6.05 \\
\hline$R e_{i}=\frac{V l_{i}}{v}$ & $251 \cdot 10^{6}$ & $17.3 \cdot 10^{6}$ & $13.8 \cdot 10^{6}$ & $26.7 \cdot 10^{6}$ & $46.3 \cdot 10^{6}$ \\
\hline$C_{f i}=\frac{0.074}{\sqrt[5]{R e_{i}}}$ & 0.00155 & 0.00264 & 0.00276 & 0.00242 & 0.00217 \\
\hline$S_{e i}\left[\mathrm{~m}^{2}\right]$ & 214.3 & 109.2 & 33.6 & 28.6 & 61.2 \\
\hline$S_{e i} \cdot C_{f i}\left[\mathrm{~m}^{2}\right]$ & 0.332 & 0.288 & 0.092 & 0.070 & 0.132 \\
\hline
\end{tabular}

$\begin{aligned} C_{A f l} & =\left(\frac{1}{S_{r e f}} \int_{S_{e}} \bar{\tau}_{x} d S\right)_{l} \approx\left(\frac{\sum S_{e i} C_{f i}}{S_{r e f}}\right)_{l}=\frac{0.914}{63.4}= \\ & =0.0144\end{aligned}$

The skin friction of the wind tunnel model is estimated with the same approach used for estimating the skin friction coefficient of the aircraft in flight. The maximum velocity in the test section of the small wind tunnel is $V=50 \mathrm{~m} / \mathrm{s}$ and the kinematic viscosity is $v=1.4607 \cdot 10^{-5} \mathrm{~m}^{2} / \mathrm{s}$. For a $1: 100$ model made with the additional technology and accuracy of $0.2 \mathrm{~mm}$, it can be expected that the average surface roughness height $h$ is at least ten times smaller, e.g. $0.02 \mathrm{~mm}$ or $20 \mu \mathrm{m}$, or probably even less. This surface roughness gives the roughness Reynolds number equal to: $\operatorname{Re}_{h}=\frac{V \cdot h}{v}=\frac{50 \cdot 20 \cdot 10^{-6}}{1.46 \cdot 10^{-5}}=68.5$.

For $R e_{h}=68.5$ and velocity of $50 \mathrm{~m} / \mathrm{s}$, the transition Reynolds number is $R e_{t}=7 \cdot 10^{6}$ from [10]. The position of transition from laminar to turbulent boundary layer derived from transition Reynolds number is $l_{t}=2 \mathrm{~m}$. It means that the laminar boundary layer is longer than the longest model dimension and that boundary layer can be taken as laminar at all parts. For the laminar skin friction coefficient, the equation $C_{f}=\frac{1.327}{\sqrt{R e}}$ is used. Table 2 shows the calculated skin friction coefficients for every part of the 1:100 wind tunnel model.

The total skin friction coefficient for the wind tunnel model is:

$$
\begin{aligned}
C_{A f m} & =\left(\frac{1}{S_{r e f}} \int_{S_{e}} \bar{\tau}_{x} d S\right)_{m} \approx\left(\frac{\sum S_{e i} C_{f i}}{S_{r e f}}\right)_{m}=\frac{124.3}{6340}= \\
& =0.0195
\end{aligned}
$$

The difference of the skin friction coefficients (16-18) gives: $\Delta_{f} C_{A}=C_{A f l}-C_{A f m}=0.0144-0.0196=-0.0052$.

\subsection{The second part of the axial correction}

It is accepted that the difference between the second parts of the axial coefficients given by Equation 13 is only the difference due to the pressure distribution on the afterbody: $\Delta_{p} C_{A}=\left(C_{A p}\right)_{l}-\left(C_{A p}\right)_{m}=\left(C_{A \beta}\right)_{l}-\left(C_{A \beta}\right)_{m}$. 
Table 2 - Friction coefficients for wind tunnel model with $50 \mathrm{~m} / \mathrm{s}$ and at ISA/SL

\begin{tabular}{||c|c|c|c|c|c|}
\hline Part $i$ & Body & Wing & Horizontal tail & Vertical tail & Nacelle \\
\hline \hline$l_{i}[\mathrm{~m}]$ & 0.328 & 0.0226 & 0.0181 & 0.0349 & 0.0605 \\
\hline$R e_{i}=\frac{V l_{i}}{v}$ & $11.2 \cdot 10^{5}$ & $0.774 \cdot 10^{5}$ & $0.620 \cdot 10^{5}$ & $1.20 \cdot 10^{5}$ & $2.07 \cdot 10^{5}$ \\
\hline$C_{f i}=\frac{1.327}{\sqrt{R e_{i}}}$ & 0.00125 & 0.00477 & 0.00533 & 0.00383 & 0.00292 \\
\hline$S_{e i}\left[\mathrm{~mm}^{2}\right]$ & 20,393 & 10,920 & 3,360 & 2,860 & 6,120 \\
\hline$S_{e i} \cdot C_{f i}\left[\mathrm{~mm}^{2}\right]$ & 25.49 & 52.08 & 17.9 & 10.96 & 17.88 \\
\hline
\end{tabular}

The boat-tail pressure-drag coefficient $\left(C_{A \beta}\right)_{l}$ is given in the literature [11] for boat-tail angle $\beta$, base-body diameter ratio $d_{b} / d$, and Mach number. The airplane parameters $d_{b} / d,=0.20$ and $\beta=7^{\circ}$ for $M a \leq 0.6$ give $\left(C_{A \beta}\right)_{l}=-0.060$, and the airplane model parameters $d_{b} / d=0.52$ and $\beta=7^{\circ}$ give $\left(C_{A \beta}\right)_{m}=\left(C_{A \beta}\right)_{l} \cdot \sqrt{1-\left(\frac{d 0 x}{d}\right)_{m}^{2}}$ $=-0.060 \cdot \sqrt{1-0.52^{2}}=-0.051$.

Both results are given for the cross-sectional area of the body $S_{B}$ as a reference surface. Therefore, the calculated difference must be reduced for the reference surface of the airplane. Since $S_{B} / S_{\text {ref }}=0.090$, finally it is: $\Delta_{p} C_{A}=-(0.060-0.051) \cdot 0.090=-0.00081$.

\subsection{The third part of axial correction}

$$
\Delta_{s} C_{A}=\left(-C_{p b} \frac{S_{b}}{S_{r e f}}\right)_{l}-\left(-C_{p r} \frac{S_{0 x}-S_{s}}{S_{r e f}}\right)_{m}
$$

The $S_{b}$ is very small for the airplane, meaning that the airplane base drag will also be very small. To calculate the second member in Equation 14, the increase of axial coefficient due to model support interferences, it is necessary to measure the pressure $C_{p r}$ in the ring between the hole and sting. In this paper, for prediction purposes only, the influence of the sting on this pressure is neglected and used as $C_{p b}=C_{p r}=-0.12$, according to literature [9]. For the sting diameter of $10 \mathrm{~mm}$, it follows that $S_{S}=78.5 \mathrm{~mm}^{2}$, and if the cross section diameter is $12 \mathrm{~mm}, S_{0 x}=113 \mathrm{~mm}^{2}$. Therefore,

$$
\Delta_{S} C_{A}=0.12 \cdot 0.20^{2}-0.12 \cdot \frac{113-78.5}{573}=-0.00243 \text {. }
$$

It follows that for $S_{B} / S_{r e f}=0.090, \Delta_{S} C_{A}=-0.00243 \cdot 0.090$ $=-0.00022$.

\subsection{The total axial force coefficient correction}

$$
\begin{aligned}
& \Delta C_{A}=\Delta_{f} C_{A}+\Delta_{p} C_{A}+\Delta_{S} C_{A}=-0.0052-0.00081- \\
& -0.00022=-0.00623
\end{aligned}
$$

It follows that the axial coefficient of the airplane in flight is 62 drag counts smaller than the measured axial coefficient on the wind tunnel model.

\subsection{The normal force coefficient correction}

$\Delta_{p} C_{N}=C_{N l}-C_{N m}=\left(\frac{1}{S_{r e f}} \int_{S_{e}} C_{p} n_{e z} d S\right)_{l}-\left(\frac{1}{S_{r e f}} \int_{S_{e}} C_{p} n_{e z} d S\right)_{m}$

It is accepted that the difference defined with Equation 15 is only due to the missing part of the afterbody. Therefore, this difference is estimated simply as the difference between the normal force coefficients on the afterbodies:

$\Delta_{p} C_{N}=C_{N l}-C_{N m}=\left(C_{N \alpha l}\right)_{\text {afterbody }} \alpha-\left(C_{N \alpha m}\right)_{a f t e r b o d y} \alpha$.

The empirical method gives the value of the normal-force-curve slope at zero angle of attack due to conical boat-tailing based on the cross-sectional area of the body as reference surface for airplane in flight, Equation 19, and model Equation 20 :

$$
\begin{aligned}
& \left(C_{\text {Nal }}\right)_{\text {afterbody }}=-2 \cdot\left[1-\left(\frac{d_{b}}{d}\right)^{2}\right]=-2 \cdot\left(1-0.20^{2}\right)=-1.92 \\
& \left(C_{\text {Nam }}\right)_{\text {afterbody }}=-2 \cdot\left(1-\frac{S_{0 x}}{S_{r e f}}\right)_{m}=-2 \cdot\left(1-\frac{113}{573}\right)=-1.61
\end{aligned}
$$

Therefore, the correction of the normal-force-curveslope $C_{N \alpha}$ coefficient for the reference surface $S_{r e f}$ is given by: $\Delta_{p} C_{N \alpha}=\left(C_{N \alpha l}-C_{N \alpha m}\right) \frac{S_{B}}{S_{r e f}}=[-1.92-(-1.61)]$. $0.090=-0.028$.

This value is of the same order of magnitude as measurement errors, since $C_{N \alpha l}=6.32$ [13].

\section{CONCLUSION}

The problem of aerodynamic coefficients estimation in a small subsonic wind tunnel regarding corrections has been addressed in this paper. The problem consists of evaluating the sting support interference, pressure distribution differences, and Reynolds number effects for a 1:100 regional turboprop aircraft in air flow with low subsonic velocity. The results of this research indicate that the Reynolds number effects are very high and that wind tunnel AT-1 has limited usage for aerodynamic coefficient determination of the proposed airplane. The axial force coefficient results indicate that the biggest and most important correction is due to the difference in Reynolds number. The problem of measurement setup of aerodynamic forces 
in this small wind tunnel gives in this case a correction six times smaller than Reynolds number corrections. If the axial coefficient is accepted to be about 0.0230 [13] for airplane in flight, the total axial force correction is $27 \%$ of the measured axial force. If the axial correction estimation is repeated referring to the turbulent skin friction of the tunnel model using the same approach as for the airplane in flight, the correction is even bigger. For the laminar skin friction in the tunnel $\Delta_{f} C_{A}=-0.0052$, and for the turbulent skin friction the result is $\Delta_{f} C_{A}=-0.0138$. Since the correction of the normal force slope is only $0.44 \%$, it follows that the correction of the pitching moment coefficient will also be small. The conclusion is that the coefficient of the normal force and the pitching moment can be measured in the given conditions. Regarding the axial coefficient, the necessary corrections are very important and should be carefully evaluated when considering using this wind tunnel in research activities.

\author{
Dr. SC. KAROLINA KRAJČEK NIKOLIĆ ${ }^{1}$ \\ E-mail: karolina.krajcek@fpz.hr \\ Izv. prof. dr. sc. ANITA DOMITROVIĆc ${ }^{1}$ \\ E-mail: anita.domitrovic@fpz.hr \\ ${ }^{1}$ Sveučilište u Zagrebu, Fakultet prometnih znanosti \\ Vukelićeva 4, 10000 Zagreb, Hrvatska \\ Prof. dr. sc. SLOBODAN JANKOVIĆ (u mirovini) ${ }^{2}$ \\ 2 E-mail: jeanslobodan@gmail.com \\ Sveučilište u Zagrebu, Fakultet strojarstva i brodogradnje \\ Ivana Lučića 5, 10000 Zagreb, Hrvatska
}

\section{PROCJENA AERODINAMIČKIH KOEFICIJENATA U MALOM PODZVUČNOM AEROTUNELU}

\section{SAŽETAK}

Kako bi se podaci izmjereni na umanjenom modelu zrakoplova $u$ aerotunelu, koristili za model zrakoplova $u$ letu, potrebno je zadovoljiti uvjete dinamičke sličnosti ili primijeniti metode korekcije podataka. Metode korekcije podataka iz aerotunela trebale bi korigirati podatke uslijed korištenja potpore modela, interferencije zidova i razlike $u$ Reynoldsovom broju. Današnje metode korekcije podatak iz aerotunela koriste CFD metode $u$ kombinaciji s mjerenjima u kriogenim zračnim tunelima. Postoji nekoliko metoda koje omogućuju preliminarni izračun tipičnih korekcija s obzirom na konkretne uvjete mjerenja i ograničenja radne sekcije. Svrha ovog rada je prikazati jedan od mogućih pristupa za procjenu korekcija podataka zbog razlike u Reynoldsovom broju između stvarnog zrakoplova u režimu krstarenja i njegovog 100 puta manjeg modela u aerotunelu AT-1. Analizom su dobiveni rezultati za korekciju aksijalnih i normalnih koeficijenata aerodinamičke sile. Rezultati analize pokazuju kako je utjecaj Reynoldsovog broja i problem instalacije unutrašnje vage vrlo velik. Prema tome, aerotunel AT-1 ima ograničenu mogućnost korištenja za određivanje aerodinamičkih koeficijenata transportnog zrakoplova kao što je zrakoplov Dash 8 Q400 koji je korišten za analizu u ovom radu.

\section{KLUČNE RIJEČI}

korekcije $u$ aerotunelu; korekcije zbog Reynoldsovog broja; korekcije zbog potpore modela;

\section{REFERENCES}

[1] Pettersson K, Rizzi A. Aerodynamic Scaling to Free Flight Conditions: Past and Present. Progress in Aerospace Sciences. 2008;44(4): 295-313.

[2] Barlow JB, Rae WH, Pope A. Low-Speed Wind Tunnel Testing. New York: John Wiley \&Sons; 1999.

[3] Horsten BJC. Low-Speed Model Support Interference Elements of an Expert System. PhD thesis. Delft: Delft University of Technology; 2009.

[4] Bushnell DM. Scaling: Wind Tunnel to Flight. Annual Review of Fluid Mechanics. 2006;38: 111-128.

[5] Traub LW. Drag Extrapolation to Higher Reynolds Number. Journal of Aircraft. 2009;46(4): 1458-1461.

[6] Mirzaei M, Karimi MH, Vaziri MA. An Investigation of a Tactical Cargo Aircraft Aft Body Drag Reduction Based on CFD Analysis and Wind Tunnel Tests. Aerospace Science and Technology. 2012;23(1): 263-269.

[7] Pettersson K, Rizzi A. Reynolds Number Effects Identified with CFD Methods Compared to Semi-Empirical Methods. In: Proceedings of the $25^{\text {th }}$ International Congress of the Aeronautical Sciences (ICAS 2006), 3 - 8 September 2006, Hamburg, Germany. Curran Associates, Inc; 2006. p. 1566-1579.

[8] Maina M, Corby N, Crocker EL, Hammond PJ, Wong PWC. A feasiblity study on designing model support systems for a blended wing body configuration in a transonic wind tunnel. Aeronautical Journal. 2006;110(1103): 53-62.

[9] Rudnik R, Germain E. Reynolds Number Scaling Effects on the European High-Lift Project Configurations. Journal of Aircraft. 2009;46(4): 1140-1151.

[10] Pamadi B. Performance, Stability, Dynamics, and Control of Airplanes. Reston, Virginia: AIAA; 1998.

[11] Janković S. [Aircraft Flight Mechanics]. Zagreb: Faculty of Mechanical Engineering and Naval Architecture; 2002. Croatian

[12] Лебедев АА. Аинамика полета: Машиностроение. Москва; 1973.

[13] Janković S. [Aerodynamic Coefficients Estimation for Dash 8 Q400 in Flight]. Zagreb: Faculty of Transport and Traffic Sciences; 2017. Croatian 